\title{
Regular Habits and a Conducive Environment in The Treatment of Children with Delayed Speech Development
}

\author{
Suharti \\ Magister Student Early Childhood Education \\ Universitas Negeri Jakarta \\ Jakarta, Indonesia \\ cucu.suharti249@gmail.com
}

\begin{abstract}
Humans as social beings cannot be separated from language. Because with language, people can communicate with others. The development of this language becomes an integral part of cognitive development. The development of the identified language goes hand in hand with human growth. When humans express something they want to express, they produce sounds called language. Furthermore, the use of language to reflect the abilities that exist in the self and only humans are able to do it. The development of language will increase in accordance with the increasing age of the child. In childhood language development is very important, so it needs to be stimulated. But in fact, the last few decades found many children with speech delay, especially the delay of functional talk. The purpose of this study is to explain efforts undertaken process carried out in LaaTahzanIslamic School Cirebon. This research is a qualitative case study. The main data sources of this research are the principal, teachers, and students in Play group and Kindergarten LaaTahzan Islamic School Cirebon. Collecting data using the method of observation, interview, and documentation.
\end{abstract}

Keywords-languange; delay speech; special need education; stimulated; regular habits; conducive environment

\section{INTRODUCTION}

The potential of a child's language, will not work optimally, without the stimulation of the environment in the golden age of growth. The ability to listen and speak are the two major aspects of language to be maximally developed, during the critical period of child language development [1]

The development of the times has an effect on the pattern of relationships between parents and children. The demands of life that are accompanied also by changes in lifestyle, further stretch the warm relationship between parents and the child. More parent's time is spent in the office and on the go. His role as the first educator in his child's critical development period was delegated to caregivers and gadgets.

Lack of parental understanding of the importance of performing its role as a 'teacher' for the child, by interacting with the child through intimate personal relationships, can unknowingly impede child development. In this digital age, many parents consider having facilitated children with TV and gadgets. A common practice is that if the child is fussy and uncontrollable, the parent assumes that it is enough to provide games through the gadget or turn on the TV for the switching material. The child will indeed stop fussing, but further interest will be formed on the electronic goods. So at other times, it will charge the activities of playing games or watching TV and will be fussy if not met. If you continue to be obeyed, your child becomes addicted. Children who are addicted to using gadgets will be hampered aspects of its development.

The ability to use language is instinctive, but the capacity for each person is different, depending on what type of specific language is used. A child born in the midst of an Indonesian-speaking adult will always listen to the language so that the child will speak the Indonesian language.

According to Hurlock [2], when the child is unable to speak like any other child of equal age, the child may be said to have a speech delay.If the level of speech development is below the level of quality of development of the same age that can be known from the accuracy of the use of words, children will be hampered as well as if their playing skills are below the peer skills.

\section{METHODOLOGY}

This research was conducted in Cirebon LaaTahzan Islamic School. The participants were teachers and students of the school academic year 2016/2017. The research method used was a descriptive study. Descriptive Study is a research method that seeks to describe and to interpret the object in accordance with what is observed [3]. Data collection techniques used was interviews, documentary studies, and observations. The instruments used were in the form of interview guidelines, observation guidelines, and documentation guidelines. This study is limited to the problem of functional delayed speech..

\section{FINDING AND DISCUSSION}

\section{A. Constraints in developing speaking skills}

In relation to speaking skills, the following obstacles children face in developing such skills are based on observations made at La Tahzan Islamic School: 


\section{1) Constraints in the acquisition of vocabulary}

Children who do not often hear other people's conversations and engage directly in communication include fewer words in his vocabulary bank. The acquisition of his new words only comes from gadgets and TV. When viewed, the words in the games are dominated by English. Then automatically, the child will be more accustomed to hearing the foreign language. Of course, it will not be a problem if the social environment supports the use of the foreign language. However, the child will have problems if otherwise. There will be confusion for the child in using the words.

As a sponge, at this time the child absorbs in total all the sounds he hears. If he interacts more with TV, for example, multiple words, unfiltered will go into his memory. Includes what sounds and actions he or she is watching.

Activity watching and playing games to make children focused on the sounds issued electronic devices. The child becomes insensitive to the human voice directly and tends to ignore it. This shows the lack of ability of children in listening.

With at least the acquisition of words at critical moments of language development, the collection of words will be minimal. The lack of vocabulary will make the child difficulties in expression and express his feelings or desires verbally. The tendency is that the child often mumbles, saying, "Mmmm, mmm ..." rather than talking. In other words, the child becomes uncommunicative.

\section{2) Constraints in pronunciation}

Listening skills have a very important role to support a child's ability to speak. The child's ability to speak a word is closely related to his or her skill in listening. The more a child hears the human voice in oral communication, it will train the child to imitate and utter the words. Vice versa. Children who are not trained to listen will have difficulty in saying the word.

Non-language sound pronunciation will be easier to imitate children who often use gadgets or watch TV, such as laughter, crying, shouting, etc. Children may also mimic the behavior of game or TV characters when laughing or angry. However, for the sound of language, the child will imitate the perfunctory mode without understanding its meaning and may not necessarily be applied in his life.

At the age of 3 years, the child should be able to combine two words, for example: "Wanna sleep." Or "Papa came." Children of this age can normally say $2 / 3$ of all consonants correctly. There are several letters that are not yet able to be spoken, such as the letters r, s, and z. However, children who are rarely talked about may experience a longer lisp. The sleeves referred to here are lisp because of habit and not because of nerve damage. This is because the articulators are not trained to use. For Indonesian children, especially for the pronunciation of $\mathrm{r}$ and $\mathrm{s}$. For ' $r$ ' will be pronounced with 'l', for example the word 'home' is pronounced with 'home', 'ice cream' is said to be 'eskim'. And the word 'milk' is pronounced with 'grandchildren'.

To correct the wrong pronunciation, the child needs the help of an adult. The learning process in this period takes place at any time. Because the needs of children in communicating will always require stimulation and revision in pronunciation. In fact, many parents do not understand the importance of teaching children to pronounce words correctly. There are still many parents who communicate with their children using slurred language but can speak normally. This is due to the assumption, that the need to adjust in communicating with small children so that children can easily understand. Yet by doing that, the child will not realize his mistake and will.

The cause of lisp there is 2 kinds, first nerve damage and lack of stimulant in the critical period of child speech development. The less intensity of the use of articulator tools, such as tongue and oral cavity, the muscles in the tools do not develop optimally.

This incorrect pronunciation or lisp if not fixed from the beginning, will continue until the child is big [4]. As a result, if it were not for the damage to his brain's nerves, a child who has grown up, needs special therapy, speech therapy. Therapy should be done with these experts, including breathing exercises and pronunciation of certain letters, which require the coordination of the tongue and other oral cavities.

\section{3) Constraints in expression}

Children who are accustomed to solitary activities (alone) without interaction with others, not trained to express. Even if he absorbs the voice of conversation from the people around him, but because it does not get the strength of meaning let alone use it, then the child has no understanding of the content of the conversation.

The results of this observation are similar to the results of a study led by Prof.Linda Pagani of the University of Montreal, found that For two-year-old infants, every hour of an excess watch from a two-hour watch time limit can have a negative impact on his academic ability and he is at higher risk -bully. This is because they are not enough to follow the process of raising oneself because of concentration and physical problems are not healthy fit. This study is the first study to find an association between too much television viewing and the risk of infants with poor motor skills and psychosocial problems.

From the results of the above research can be seen that children who rarely interact with others, do not experience good physical growth. Physical growth is also associated with nerve and motor growth, including the articulator's muscles. The lack of maximum physical growth, affecting his psychological condition. Emotional development is not honed [5]. Emotion is the forerunner of expression. With the emotion, the child will behave in accordance with his emotions. To express it, children need a model of what is seen or heard.

If the child often watches TV or play games that smell of violence or scenes of angry people or fights, then that's what he will disclose. She would scream like the characters she watched on TV or crying around when she was angry. Without the ability to communicate verbally. In this regard, based on research involving 3,000 children 3-year-olds, found that 
children who watch TV too often, directly or indirectly, are at risk of showing off aggressive behavior.

Inability to express feelings and emotions will make children irritable and depressed. To ask for something she wants, the child should be able to say verbally to her parents. However, due to the limited ability to speak, parents cannot understand it. As a result, the child becomes crying, angry, or sulking. When asked nicely, a child who is not trained to speak will tend to murmur, "Mmmm, mmm ..." which is not an explanation.

\section{4) Constraints in social interaction}

Social interaction is the ultimate manifestation that man is a social being. The ability to interact socially or often said with socialization is not something that is done immediately [6]. This requires a process that is installed and trained from an early age, ie from the golden age of one's growth.For children living in the neighborhood, where the distance between houses is not limited to high fences, children will be more easily interact. Unlike the case with children who live in housing surrounded by fences. When the parents work, the child is accompanied by a caregiver who does not necessarily have the ability to educate children. Instead of being invited to play outside with the children her age, the child is given a gadget or a spectacle to pass the time.

Regular activities offered by parents in the form of TV or games through gadgets, provide prolonged impact. Children will be more interested in the activity than to interact with others, such as playing with peers. Though playing in childhood is an important learning process for children. Not only to hone their ability to socialize, through games, moral values can also be sharpened and implanted. For example, the value of compassion, sharing, respect, cooperation, and so on.

By playing together, children are required to communicate verbally [7]. Of course according to his ability. From that process, her ability to speak will increase. Children in the golden age of growing used to interact with others, especially with two-way communication, will have high confidence. Conversely, children who are not accustomed to interacting with others, will form into a closed person, can even experience a social phobia, minder, and fear if in the middle of the crowd. Worse yet, children can become anti-social.

\section{B. Treatment for children with delayed speech}

Early-age children who experience late speech should be done early detection so that can be designed appropriate stimulation with a variety of activities that will help overcome delayed speech . Treatment is done at Laa Tahzan Islamic School Cirebon for children with speech delay:

\section{1) Regular Habits}

Regular habitation in question is to condition the child with a delay in speaking in accordance with the daily schedule that has been prepared by the teacher for Regular habituation at school and by parents for Regular habituation at home. This handling program involves parents intensively. Therefore, before the child enters school the school interviews the real conditions of the home and agreements not to cover all the information needed to find out the initial cause of the child who is in a speech position. Regular habits performed at school and at home should be in sync. Regular habituation done in the school is making a schedule to talk face to face with the teacher responsible for the practice of speaking with the right pronunciation of the goal so that children with speech delay can practice regular speaking skills; create a play schedule with friends in turns that aims to enable children to use the language they have begun to acquire functionally used in the socialization process by playing; familiarize children to talk when they want something not with body language like pointing fingers.

\section{2) Conducive environment}

What can be done to design activities to address children with delay in speaking at school is to facilitate a conducive environment during learning process implementation to help with delayed speech handling. The design is as follows:

- Appoint the teacher responsible for the child's Speech delay. The teacher is tasked with providing special stimulation and noting the progress of child development Speech delay.

- Create a stimulation plan for the Speech delay child as part of an effort for language development. This stimulation includes:

- Identify letters and words that have been able to produce and which have not been able to be produced.

- Teach simple meaningful words that are often used for example drinking, eating, teacher's mother, friends, bags, supplies, and so on. For the beginning while showing the object and mentioned many times. For example, when Fatih wants to drink, Fatih just tugs at the teacher's clothes and says, "hah ... hah ...", The teachers affirm with the word, "Drink?" While demonstrating the drinking motion and pointing to the drinking bottle. "Drinking" repeatedly said drinking mentioned by the teacher's mother. The taught words still focus on one word consisting of two syllables.

- Teach two meaningful words of subject and verb. For example Fatih drink and so on.

- Speaking and making sure there is eye contact with Speech delay child while occasionally asking the child to repeat, although not yet meaningful but still giving the opportunity and appreciate, the goal is that children are not afraid to speak

- Cooperating with parents to teach the words being taught in school is repeated and re-taught at home.

- Learn the diagnostic results of pediatricians, psychologists, and therapists and synchronize with the next stimulation plan that will be done to children Speech delay

- Report the progressive progress of delayed speech children's language to parents on a regular basis and discuss with parents the progress that has been achieved at home. 
Based on observations conducted at Laa Tahzan Islamic School on children who experienced speech delays and given treatment provide Regular habituation schedule and a conducive environment there are significant results. Children who have been treated have a better change of speech skills. If previously communicated only using the gesture of the body, the child who has been treated has begun to communicate two ways using simple sentences. Besides that, the child is still able to socialize with peers using verbal language.

\section{CONCLUSION AND SUGGESTION}

Knowledge of language especially knowledge about development phase of language aspect of talking to children must be understood by educator and parent. This knowledge can detect as early as possible if there are obstacles or delay in talking to the child, so that can immediately intervene and appropriate handling to overcome them. To optimize the ability to speak, children need stimulation in the form of interaction and communication with others.

Parents are the most responsible parties in the successful development of children in this period [8]. Stimulation can be given by parents with an intense conversation with children, and limiting television viewing, playing gadgets and the like so that language acquisition directly related to the ability to talk through role models can be done selectively. The use of language for the stimulation of early childhood speech is more emphasized on the functional vocabulary that can be directly applied to the daily activities of children [9]. So, that children are not only able to speak, but can also understand the meaning of the spoken word and use it in the context of the right simple sentence .

Besides parents, teachers at school can help to provide treatment for children with speech delay by giving treatment one of them by doing regular habituation and a conducive environment.

\section{References}

[1] Brown, H. D. Prinsip Pembelajaran dan Pengajaran Bahasa Edisi 5 Terjemahan N. Cholis dan Y. A. Pareanom. Jakarta: Kedutaan Besar Amerika, 2008

[2] Hurlock, Elizabeth B. Perkembangan Anak : Jilid 2. Penerbit Erlangga : Jakarta, 2012

[3] Sukmadinata, N. S. Metode Penelitian Pendidikan. Bandung. Remaja Rosdakarya, 2005

[4] Beyeng, Rosalia dkk . Prevalensi dan Karakteristik Keterlambatan Bicara pada Anak Prasekolah di TPA Werdhi Kumara 1 Dengan Early Language Milestone Scale-2, 2012

[5] Bishop DV). Developmental disorders of speech and language, Oxford: Blackwell Science, 1994

[6] Rini Hildayani, Dkk,Psikologi Perkembangan Anak, Jakarta; Universitas Terbuka, 2005.

[7] Santrock. J. W. Psikologi Pendidikan. Jakarta:Salemba Humanika. 2011.

[8] Santrock, J.W. Perkembangan Anak Edisi 11 Terjemahan Mila Rachmawati \& Anna Kuswanti. Jakarta: Erlangga, 2007.

[9] Upton, Penney. Psikologi Perkembangan Terjemahan Noermalasari Fajar Widuri, Jakarta: Erlangga, 2012 